
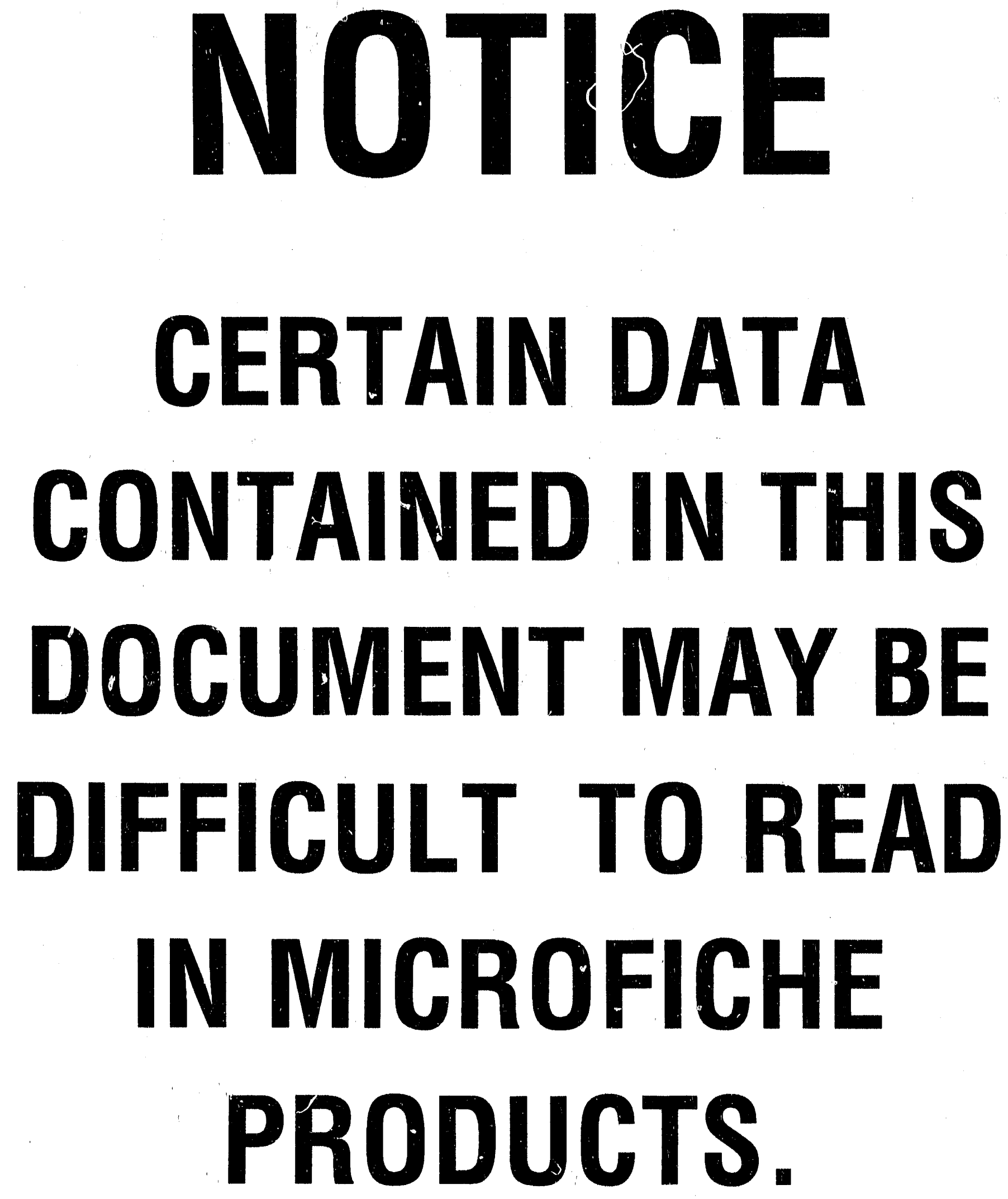


\section{LEVELS OE RADIOACTIVITY IN FISH FROM STREAMS NEAR F-AREA AND H-AREA SEEPAGE BASINS (U)}

Charles E. Muzhy, ir., Environmental Sciences section

Craig Loenie, Environmutal Sciences Section

APPROVED BY:

D. 3. MOORE, SECTION MANAGER

ENVIROMMENTAL SCIENCES SECTION

PUBLICATIC: DATE: $\because A Y, 1991$

Westinghouse Savanrah li.iver Company

\section{DISCLAIMER}

Savannah River SitE

Aiken, SC 29808

This report was prepared as an account of work sponsored by an agency of the United States Government. Neither the United States Government nor any agency thereof, nor any of their employees, makes any warranty, express or implied, or assumes any legal liability or responsibility for the accuracy, completeness, or usefulness of any information, apparatus, product, or process disclosed, or represents that its use would not infringe privately owned rights. Reference herein to any specific commercial product, process, or service by trade name, trademark, manufacturer, or otherwise does not necessarily constitute or imply its endorsement, recommendation, or favoring by the United States Government or any agency thereof. The views and opinions of authors expressed herein do not necessarily state or reflect those of the United States Government or any agency thereof.

This informat:a candined in this article was developed during the course sf iork incier Contract No. DE-AC09-89SR18035. 


\section{SUMMARY}

This report summar: $\cdots$. results of recent analyses of radioactivity in fish from SRS etr. basins. Fish were .......ucted from headwater areas of Four Mile Creek and Eer. $\Xi$ ra:..., : $:$ m just below the H-Area seepage basin, and from three sito: winstream in Four Mile Creek. These fish were analyzed for ar..; alpha and gross beta radioactivity using standard EPA nethods.

Levels of grcss alfthi and nonvolatile beta radioactivity in fish were found to be comprable to levels previously reported for these sites. Gros: ipha activity was not found to be influenced by Separations Area i:acharges. Nonvolatile beta activity was higher in the vicinil:" ut the Separations Area discharges and the majority of the nonv. .tile beta activity was attributable to Cs137 and $\mathrm{k}-40$. The : : metric corisequences of consuming fish from this area were folin: he well below DOE guidelines.

\section{INTRODUCTION}

Until 1988, seepage lusins at F- and H-Areas of SRS received liquid effluents from : he separations areas. These liquid wastes seeped througi the uround and outcropped in the wetlands adjoining Four Mile Creek (Hasulow et al., 1990). An issue of regulatory concern is whether the resulting contamination has migrated to the creek in sufficient iliantity to contaminate fish populations. In this study we have chllected several species of fish from the area of concern and compar...l them to upstream test locations in order to test whether fiun arar or downstream from the basins have accumulated contami:: : son.

\section{METHODS}

Adult and juvenile : is were collected during July 1990 from six sample stations in $\cdots \cdot$ Mile Creek and one sample station in Pen Branch (Pallez and …rey, 1990). The approximate locations of the sampling station: : re indicated in Table 1 and Figure 1 . Site 1 represents upstrom :ontrol site on Four Mile Creek. No known sources of contamindt: in exist in the upper reach of the creek. Site 7 is a readwa..: . ntrol site on Pen Branch. Site? is below H-Area and is used: nst for seepage basin effects. Site 4 is below the cut $=a 11:: \cdots:$ reactor. For this study, sites $4 a$ and ib of Paller and Etor...: 930) were combined into a single site 4 .

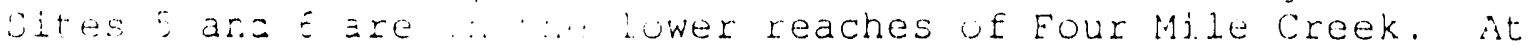
each of these Eamp... .ations, three $100 \mathrm{~m}$ stream segments were selected for Electr. : ining. Segments were measured with a measuring tape. The ... ream segments possessed representative 
habitats $\equiv .: 2$ were at least $30 \mathrm{~m}$ from roads and bridges. The segments inzee separated by at least $20 \mathrm{~m}$.

Backpack = iectrofiching (Smith Root Model 15-A, 250-watt) was conducted $\equiv=$ all sample stations. Electric current was directed around anc in brushpiles, snags, stumps, beneath undercut banks, and in ofs? water. itunned $\mathrm{fish}$ were removed from the water using $6.35 \mathrm{~mm}$ mesn dip nets; all collections were made while moving upstream $=$ roough the stream segment. A single pass was made through eas. stream ijegment.

All fish captured by plectrofishing were placed on ice. Each fish was ident: : Eed to upecies, measured (total length to nearest mm), weighed (rearest 9 ), and briefly checked for disease, parasitism, and other $\equiv$ nomalies in the field. Results of field analyses are reported :- Paller and Storey (1990).

Eish were zitted to avoid analysis of stomach contents. Whole fish (incizing bones) were analyzed by Roy F. Weston, Inc. Fish values were converted from dry to wet weight concentrations (dry to wet we:ant ratio average 0.18 ). Results by species are summarizec in Table 2 .

\section{RESUITS}

\section{Gross Alpha and Nonvolatile Beta Activity in Water}

The majoriz $\because$ of radionuclide releases to Four Mile Creek are associated with the $F$ - and H-Separations Areas. There are direct low-level zeleases of radionuclides from process outfal is and indirect zieases from migration through the ground water of water which was zeviousl $\because$ released to open seepage basins. There is also some zontribution, primarily tritium, from migration from the C Reactor zeepage hasin. Releases have been made since 1954 and the creek zediments have accumulated small amounts of contaminat: $=$ n during the period from 1954 until the present: (2eigler ar: Lawrimore, 1986).

The SRS Er $\because$ ronmental Protection Department (EPD) monitors stream water at Eaur Mile creek for gross alpha and nonvolatile beta activity $a=$ Roads $(\because, 4, A 7$, and below road $A$. Analyses are also made for $:$ sected radionuclides, including the beta emitters tritium ara strontium-39,90 and the alpha emitters uranium and plutonium.

The contrisics: : titonium and uranium to the total gross alpha activity : ver: mil: This suggests that most of the alpha activity : : Erom naturally occurring radionuclides. This cuntentior. - s supported by the low alpha activity recorded (Cummins $E: a 1 .,: 990)$ at all of the stream sampling sites 
(Figure 2). While the average alpha activity is higher in Four Mile Creek than that found in Pen Branch, an adjacent stream at SRS, the saandard deviations of both the Four Mile Creek and Pen Branch sampies are large enough that the differences are not statistica:-y significant. Furthermore, the Four Mile Creek gross alpha actïlty is nearly identical with the gross alpha activity of the Edis=0 Piver, a nearby stream which does not have any SRS streams wizhin its watershed.

In contrast to the gross alpha activity, the nonvolatile beta activity is the water column in Four Mile Creek is significantly above that cound in either Pen Branch or the Edisto River (Cummins et al., 1990). Most of the tritium in the water column is volatile and does not contribute to the measurements. The average Strontium-89,90 activity measured in Four Mile Creek is about $30 \%$ of total nonvolatile beta activity. The remainder of this activity could be from other beta emitters that are released in small quantities (for example Tc-99 or Cs-137) or naturally occurring beta emitters.

The patter: of nonvolatile beta activity in the water column at the EPD sampling site also suggests that a major part of the beta activity is from SRS releases. The activity is relatively low at the upstream monitoring stations and increases as the water moves downstream past the outfalls from the $F$ - and H-Separations Areas. The activity falls downstream of the sampling point at road $A-7$ which is below the point of most of the Separations Areas outfalls. The lower activity in the most downstream sampling point can be attributed to dilution from water added to the streamflow from the ground water.

\section{Gross Alpha and Nonvolatile Beta Activity in Fish}

The gross a:pha activity in Four Mile Creek fish is shown in Eigure 2. While it appears that there is a trend of decreasing activity with downstream distance of the sampling location, the difference between locations and the difference between each Four Mile Creek :ocation and Pen Branch is not statistically significant due to the very large standard errors. The lack of significant relationship between activity in the fish and the location of Separations Area outfalls, in addition to the fact that most : E the alpha activity in the water column appears to be from natura: alpha activity, suggests that SRS operations have little effez: on the gross alpha activity in the fish.

Because the ana-y:: lt the water column indicates ihat the nonvolatile beta activity is significantly influenced by SRS effluent discharges, it is reasonable to assume that the nonvolatile beta activity in fish would also be affected by SRS operations. Inspection of the nonvolatile beta activity of the 
fish at tre sampling locations (Eigure 3) shows a pattern similar to that $f: u n d$ in the water; the activity in the fish increases as beta act: $\because-\because y$ is added to the water from the separations Area outfalls. Zownstream f:om the Road A-7 sampling location, which is below r zst of the outfalls, the activity in the fish decreases.

While the zaneral rattern of nonvolatile beta activity is similar for the wa:er column and the fish in Four Mile Creek, the ratio of the activ: $\because$ in the fish to activity in the water for the two upstream -zations is almost double the activity ratio for the two downstrear. -ocations (Eigure 4). Both calcium, a chemical analogue ż strontium, and potassium, an analogue of cesium, are increased $: \therefore$ concentration at the downstream locations (Haselow et al.,1990). This suggests that the decreasing uptake ratio may be caused by $:=e$ increase in competing elements in the downstream locations.

For calcu- $=$ ing dose to man from consumption of sish, methods in Marter ( $1: \vdots:)$ are used. It is assumed as a worst case that all the gross E-pha is plutonium-239 and all the nonvolatile beta is strontium-: $:$. The assumed fish ingestion is $19 \mathrm{~kg} / \mathrm{yr}$. The effective zose equivalent from ingestion of plutonium-239 is $0.0043 \mathrm{mre}=\mathrm{pCi}$ and from strontium-90 is $0.00013 \mathrm{mrem} / \mathrm{pCi}$. The highest $g=z s s$ alpha concentration in this study was $0.23 \mathrm{plCi} / \mathrm{lg}$ wet we) at station 2 , with about a $.18 \mathrm{dry}$ to wet weight concentration conversion.

The concer:zation of plutonium-239 in bone is typically about 390 times that $i n$ Elesh (Blaylock, 1982) and since bones are not consumed, :-is needs to be factored out to get the concentration in the fles:. If we assume that about $10 \%$ of the fish consists of bones, the:

$$
\begin{aligned}
& 0.23 \mathrm{pCi} / \mathrm{g}=0.1 \times 390 Y+0.9 Y \\
& 0.23=39.9 Y \\
& Y=0.00577
\end{aligned}
$$

so the dr: weight concentration without bones would be about.9Y or $0.00526=\mathrm{Ci} / \mathrm{gm}$. For plutanium-239 this gives

Dose $=19 \mathrm{C}:=(\mathrm{g}$ wet $\mathrm{wt}) \times 0.00520 \mathrm{pCi} / \mathrm{g} \times 0.0043 \mathrm{mrem} / \mathrm{pCi}$ $=0 . \div \vdots$ mrem

If we ass:-e that the bones are consumed, then we merely use the whole fist : $\exists l u e$ of $0.23 \mathrm{pCi} / \mathrm{g}$ wet wt.

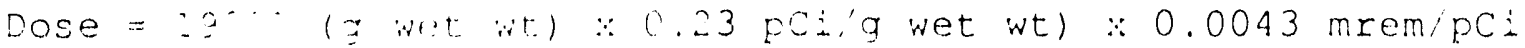
$=: \bar{\delta} \cdot \cdots \mathrm{mrem}$

Eollowing $:$ e same procedure for strontium-90 as the worst case radionucli:三 for beta, the highest value is $12.41 \mathrm{pCi} /$ g wet wt 
for statiz: 4. The ratio of strontium in bones to flesh is close to $100 \mathrm{t}=$.. This gives

$$
\begin{aligned}
& 12.41 \mathrm{pCi} / \mathrm{g}=0.1 \times 100 \mathrm{z}+0.92 \\
& 12.41=10.92 \\
& z=1.138
\end{aligned}
$$

therefore the fish without bones is .92 or about $1.0243 \mathrm{pCi} / \mathrm{g}$. The dose alculation for strontium-90 is

Dose $=19: 00$ (g wet wt) $x 1.0243 \mathrm{pCi} / \mathrm{g}$ wet wt $\times 0.00013 \mathrm{mrem} / \mathrm{pCi}$ $=2 . \vdots \vdots$ mrem

If we aga:-: assume that the bones are also consumed, then we get

Dose $=19: 00(\mathrm{~g}$ wet $\mathrm{wt}) \times 12.41 \mathrm{pCi} / \mathrm{g}$ wet wt $\times 0.00013 \mathrm{mrem} / \mathrm{pCi}$ $=30.55$ mrem

These fles: concentration values (about $0.23 \mathrm{pCi} / \mathrm{g}$ for gross alpha as pluton:u-239 and $12.41 \mathrm{pCi} / \mathrm{g}$ for nonvolatile beta as strontium-jo) are in the ranges reported in earlier studies (Cummins $E$ : al., 1990).

To assess the source of the isotope specific beta emissions, six fish from - ocation 4 were analyzed for cesium-137 by the Environmer:al Monitoring Section of WSRC. Fish of several species were analyzed as composite samples. The mean beta activity zue to cesium-137 for these six fish was $7.51 \mathrm{pCi} / \mathrm{g}$ wet wt for whate fish. This value is comparable to those found in previous $\Xi:$ dies (Cummins et al. 1990). The other nuclide that was detec:iole was potassium-40, a naturally occurring isotope, with a mes:- value ot $2.49 \mathrm{pCi} / \mathrm{g}$ wet wt. The cesium-137 and potassium- ) together account for $10 \mathrm{pCi} / \mathrm{g}$ compared to the 12.41 $\mathrm{pCi} / \mathrm{g}$ grc $\equiv$ nonvolatile beta. Thus almost all of the gross beta activity - : likely tt tributable to cesium-137 and potassium-40 in these fist., rather than to strontium-90. The dose calculation for cesium-13- is

Dose $=19:: J$ (g wet wt) $\times 7.51 \mathrm{pCi} / \mathrm{g}$ wet wt $\times 0.00005$ $=7 .: \therefore$ mrem

which is $\cdots=$ on lower than when strontium-90 is assumed.

\section{DISCUSSIC::}

From this z:udy it uppears that SRS releases into Four Mile creek have had :-tele effect on the levels of gross alpha activity in fish rela: :ie to the effect of natural or other sources unrelated to SRS ipsżtions. In the other hand, SRS operations nave 
affected $:$ :e level of nonvolatile beta activity in the water column ar: the fish. However, even in this case the effect on the fish in tais stream is quite small and potential dosimetric consequerizes of human consumption of these fish are also small. 


\section{REEERENCES}

Blaylock, $\Xi$. G., 1982. Radionuclide Data Bases Available for Bioaccumulation Factors for Ereshwater Biota. Nuclear Safety $23: 427-438$.

Cummins, Z. L., D. K. Martin, and J. L. Todd. 1990. Savannah River Site Environmental Report for 1989, Vol. II (U). WSRC-IM90-60. WSRC Environmental Protection Departmelt, Aiken, SC 29808 .

Haselow, J., M. Harris, B. B. Looney, N. V. Halverson, and J. B. Gladden, 1990. Analysis of Soil and water at the Four Mile Creek Seepline near the E\&H Areas of SRS (U). WSRC-RP-90-591. WSRC Savannah River Laboratory, Aiken, SC 29808.

Loehle, $C$. and 1 . Paller, 1990. Heavy Metals in Fish from streams near F-Area and H-Area Seepage Basins (U). WSRC-RP-90-482. WSRC Savannah Fiver Laboratory, Aiken, SC 29808.

Marter, W. :., 1991. Environmental Doses for 1990 Environmental Report. SRL-ETS-91-0129.

Paller, M. And C. Storey, 1990. Effects of Outcropping Groundwater from the $F$ - and $H$-Area Seepage Basins on the Distribution of Fish in Four Mile Creek (U). WSRC-TR-90-502. WSRC Savannah River Laboratory, Aiken, SC 29808.

Zeigler, C. C. and I. B. Lawrimore, 1988. Releases of Radioactivity at the Savannah River Plant, , 1954 through 1985. DPSU-86-25-i, Rev 6/1/88, E. I. DuPont de Nemours \& Co., Savannah River Plan:, Aiken, SC. 


\section{TABIE : . Sampling site locations on Four Mile Creok (FMC) and Pen Branch (PB).}

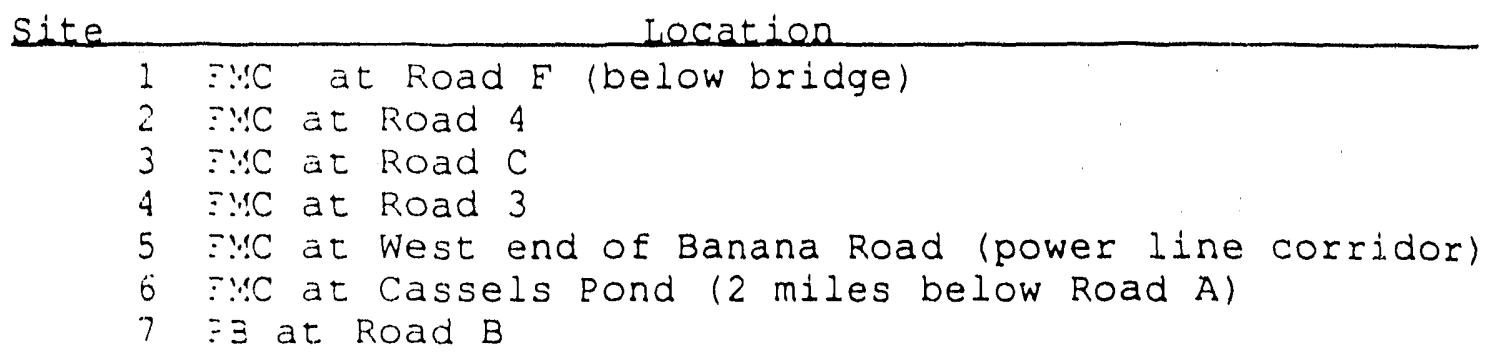


TABLE 2. Summary statistics by site and species, $\mathrm{pCl} / \mathrm{g}$ Wet Wt

Sunfishes

\begin{tabular}{llllll} 
Site & Alpha Mean & Alpha Range & Beta Mean & Beta Range \\
\hline 1 & 9 & 0.076 & 0.0 .684 & 1.06 & $0.41 \cdot 1.98$ \\
2 & IC & 0.23 & 0.0 .83 & 6.71 & $2.52 \cdot 10.98$ \\
3 & IC & 0.35 & 0.2 .16 & 6.12 & $2.70 \cdot 12.78$ \\
4 & $2 C$ & 0.033 & 0.0 .40 & 10.41 & $2.34 \cdot 18.36$ \\
5 & 9 & 0.044 & 0.0 .40 & 9.04 & $4.14 \cdot 16.20$ \\
6 & $1 C$ & 0.023 & 0.0 .23 & 5.14 & $0.25 \cdot 11.7$ \\
7 & 8 & 0 & 0.0 & 5.07 & $0.16 \cdot 15.84$ \\
\hline
\end{tabular}

Bottom Fishes ${ }^{2}$

\begin{tabular}{llllll} 
Site & $N$ & Alpha Mean & Alpha Range Beta Mean & Beta Range \\
\hline 1 & 0 & & & & \\
2 & 0 & 0 & 0.0 & 11.99 & $2.16-23.4$ \\
3 & 8 & 0.49 & 0.0 .61 & 17.92 & $7.02 \cdot 32.94$ \\
4 & 7 & & & & \\
5 & 0 & & & & \\
6 & 0 & 0 & & & \\
7 & & & & & \\
\hline
\end{tabular}

Yellowfin Shiners

\begin{tabular}{llllll} 
Site & N & Alpha Mean & Alpha Range Beta Mean & Beta Range \\
\hline 1 & 0 & & & & \\
2 & 0 & 0 & 0.0 & 8.78 & $6.48 \cdot 9.72$ \\
3 & 4 & 0 & 0.0 & 12.56 & $5.04-22.14$ \\
4 & 3 & 0 & & & \\
5 & 0 & 0 & & & \\
5 & 0 & & & & \\
7 & 0 & & & & \\
\hline
\end{tabular}

1. Includes redt':ssi sunfish. spotted sunfish and dollar suntish.

2. Includes yellow zullhead and creek chubsucker. 
Table 3. Gross alpha and non-volatile beta in fish, Eresh weight basis

\begin{tabular}{llr} 
SITE & ALPHA & (pCi/g FRESH) \\
\hline 1 & 0.0634 & 1.067 \\
2 & 0.230 & 6.714 \\
3 & 0.170 & 9.082 \\
4 & 0.0355 & 12.405 \\
5 & 0.0439 & 9.040 \\
6 & 0.0234 & 5.141 \\
7 & 0.0 & 5.069 \\
\hline
\end{tabular}




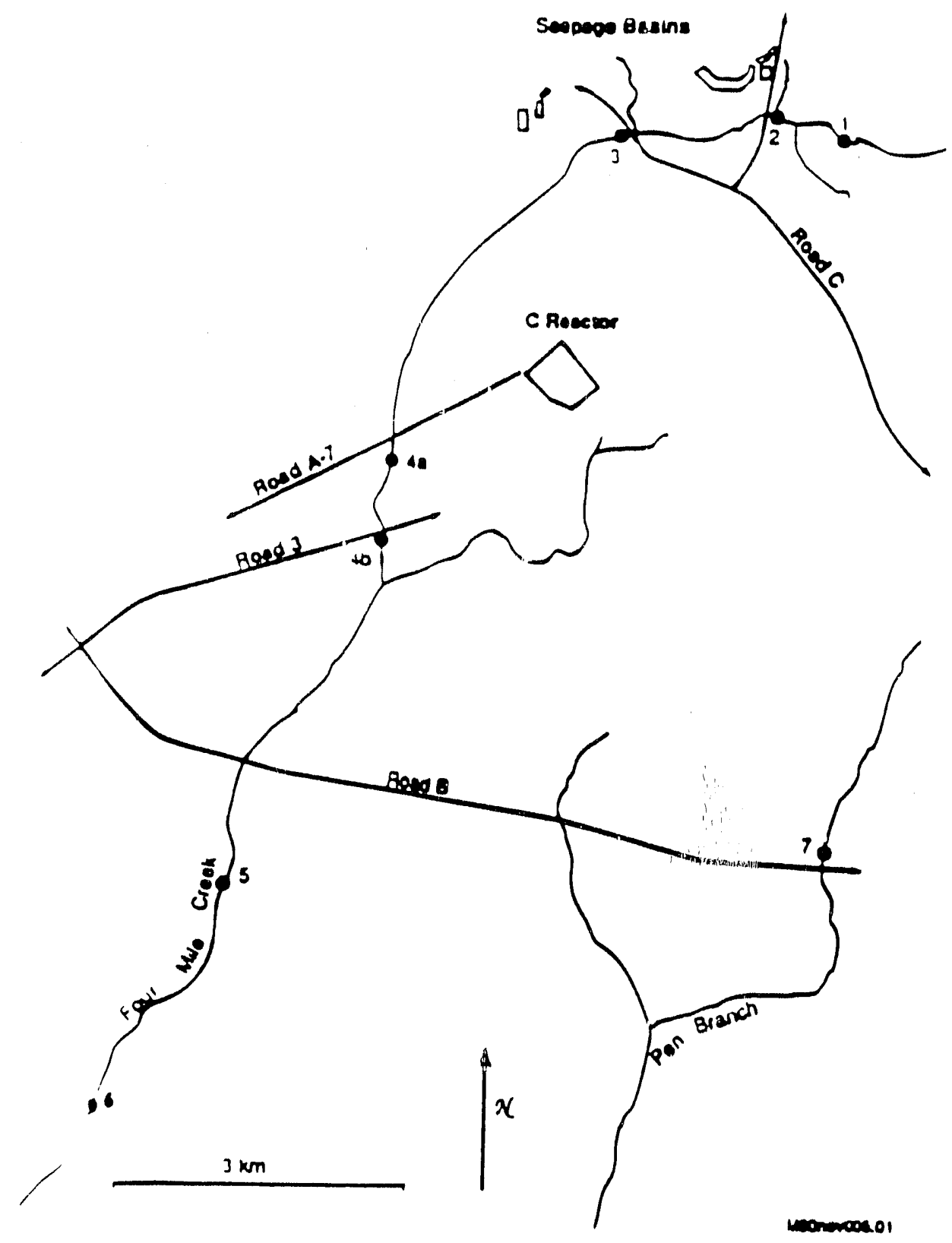

FIGUEE : FISH BAMPIING LOCATIONS 


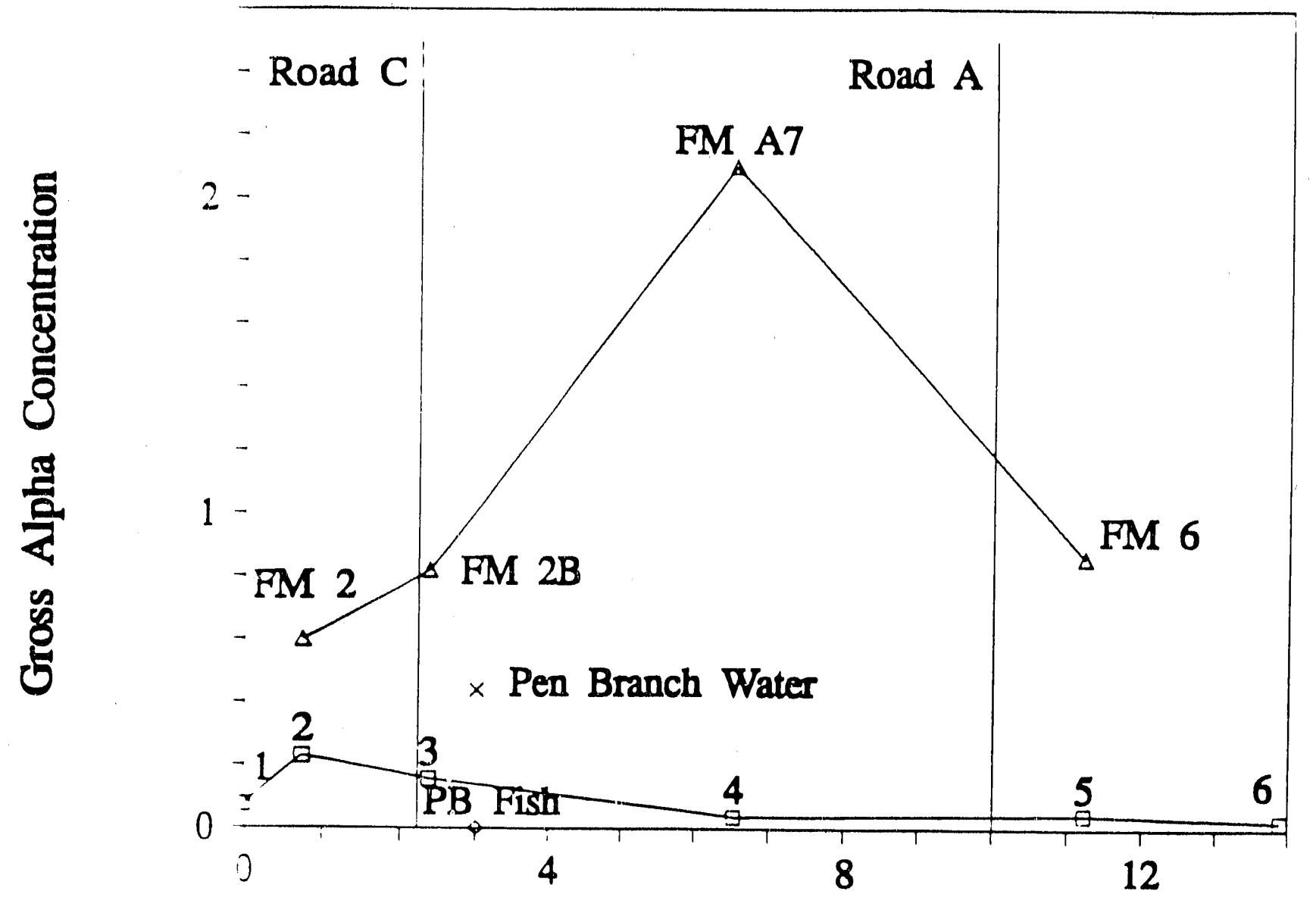

Cumulative Kilometers Downstream

Fish (pCi/gm-wet) $\quad \Delta$ Water (pCi/L)

EIGURE : ALPHA IN FOUR MILE FISH AND WATER 


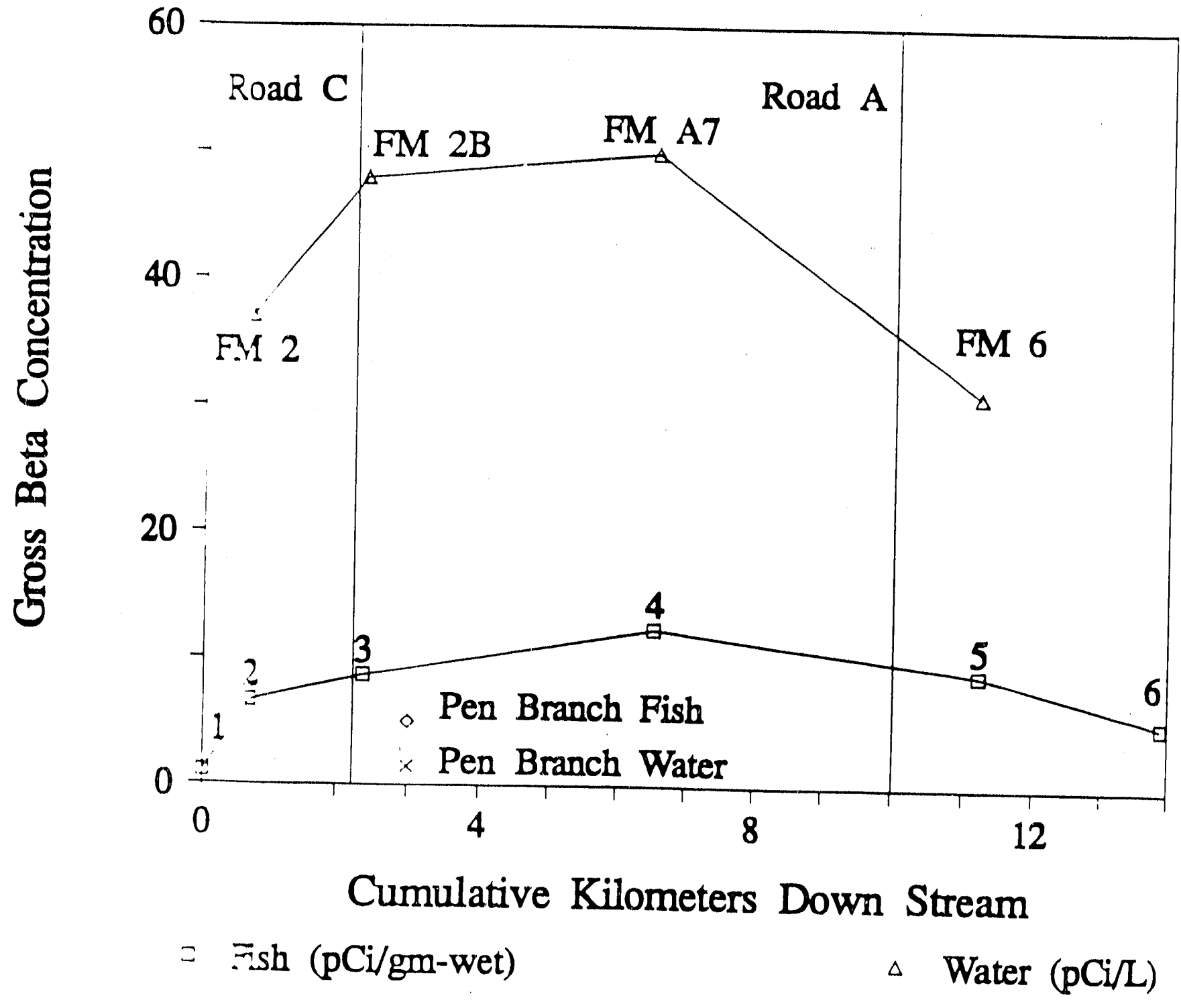

FIGURE: NONVOLATILE BETA IN FOUR MILE FISH AND WATER 


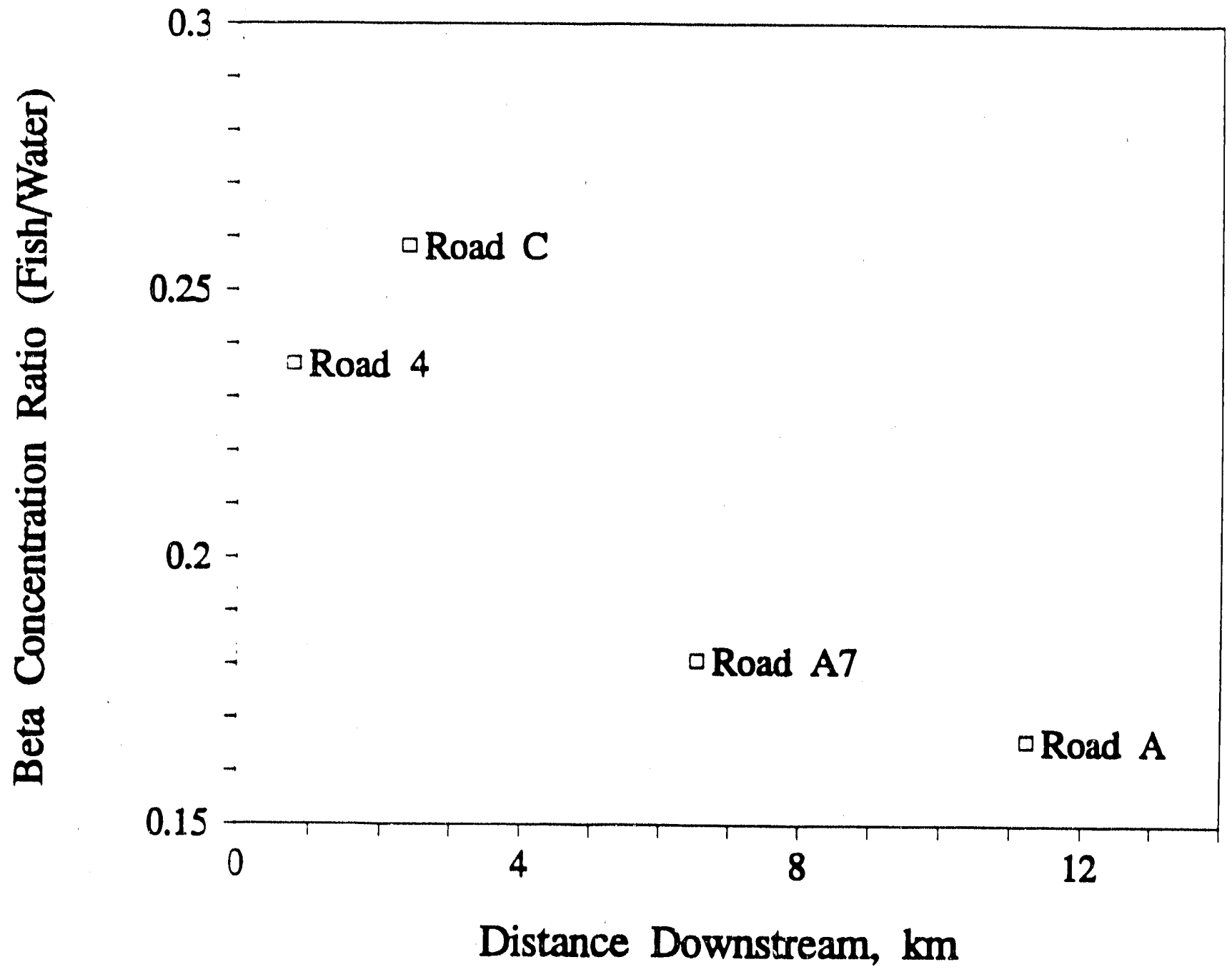

EIGURE : NONVOLATILE BETA IN FISH VS. WATER 

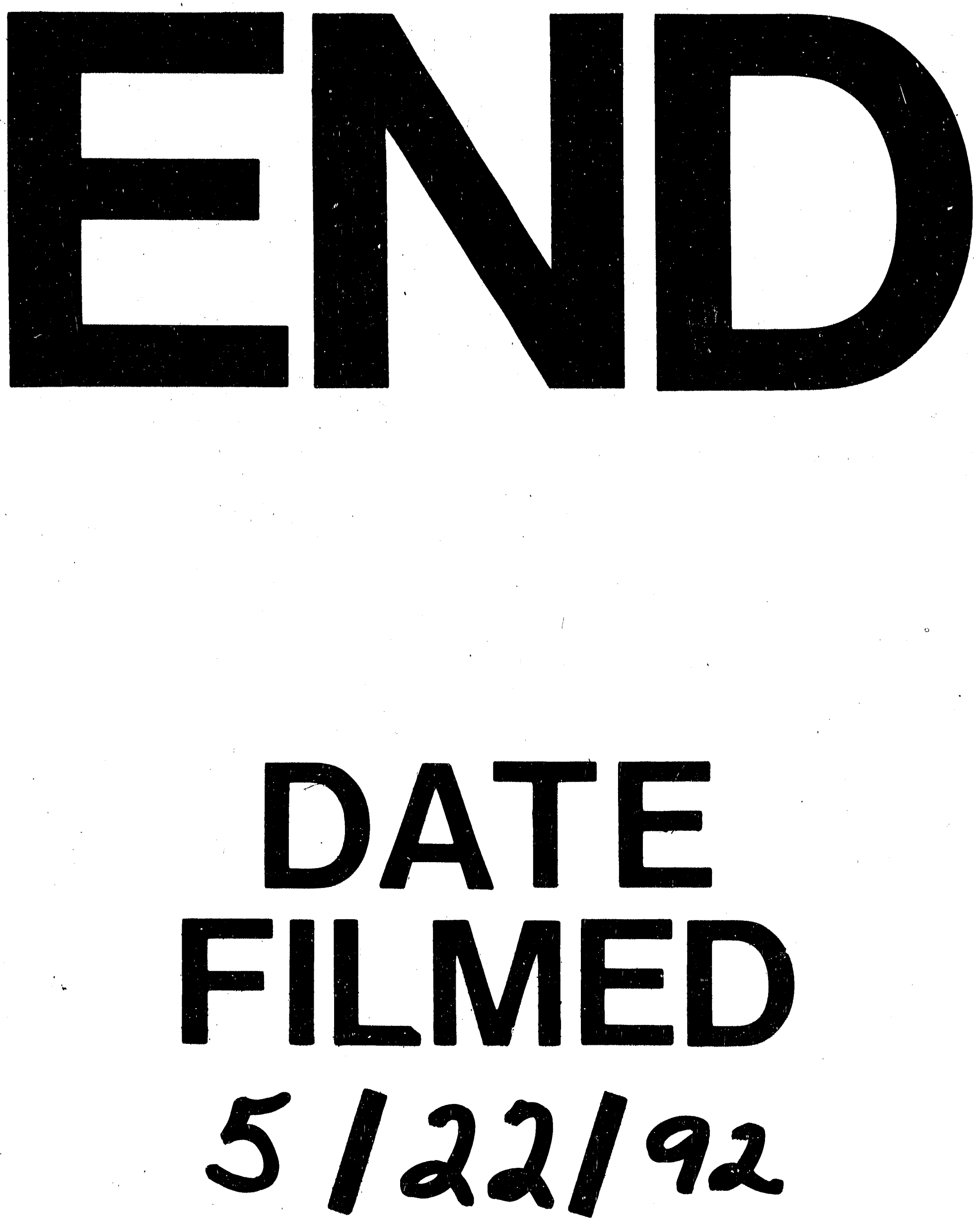

$f$ 
